\title{
Integrating Self -Reliance Skills into Food and Nutrition Curriculumn for Effective Enterprenuership Development
}

\author{
Ogori Akama Friday \\ Utim Susan M.
}

School of Vocational Studies, Federal College of Educaton Kontagora, Niger State, Nigera

\section{Doi:10.5901/jesr.2013.v3n4p91}

\begin{abstract}
Self reliance skills has been revealed to be playing very important role in the entrepreneurship development of any country as its help to alleviate issues on unemployment. In this paper the content of senior secondary school food and nutrition curriculum which promotes the acquisition of self reliance skills were identified. The self reliance skills and its importance as well as it challenges of acquisition of self reliance skills to the actualization of entrepreneurship development.proferred solutions which are, encourage curriculum planners to integrate self reliance skills into food and nutrition curricula for variety of opportunity in the labour market and also the training of in-service teachers on how to implement the schemes into class room when teaching or training students.
\end{abstract}

Keywords: Self reliance, skills, curriculum, food and nutrition

\section{Introduction}

Nigeria is getting saturated with young graduate of various disciplines that are unemployed. The numbers of graduates being churned out from Nigeria schools yearly are so enormous that absorbing them into the labour market is becoming quite impossible .unemployment had take another dimension,Fayomi(2007)and so urgent attentions are needed in this area .One way of curbing the challenge is through entrepreneurship development in Home economics, food and nutrition, gearing them towards applications of their skills in participating in private sector ventures. It is expected that entrepreneurship exposure in home economics education where food and nutrition as an aspect would help to improve the situation, since science is for life and technology the bed rock for societal growth and transformation. This will be actualized by exposing our youth to a new entrepreneurship environment in food and nutrition through curriculum. Basic education is the foundation of sustainable life long learning .It provides learner with an environment to acquire functional literacy . In Nigeria this basic education includes primary, secondary and nomadic education as well as adult literacy. Introducing self reliance skills in food and nutrition for classroom lesson delivery is an important aspect in teachers lesson plan, in that it will help integrate effectively skills that heightens student interest towards productivity. The 21 st century students should have innovative skills, developmental ideas using well developed lesson content that generate, stimulate, motivate and orientate student interest towards self -reliance skills and individual empowerment. It is necessary to provide students with an accurate picture of the requirement and opportunity involved in many careers available in food and nutrition. Consequently upon this, the researcher cleared its importance that food and nutrition teaching should involve creative ways of integrating acquisition of self -reliance skills into food and nutrition 
curriculum, this model of learning will not only help achieve the objective of food and Nutrition education but also its enterpreurship development.

\section{Self -Reliance Skills and Importance}

The key to any meaning development in entrepreneurship however can only be found in deliberate human development. Such development must be sustained, every training in human development should be geared towards capacity building. It is for this reason that the new food and nutrition curriculum has to do with self reliance skills acquisition and development; ability to apply scientific skills to everyday life on matter of personal, community, nurition, health and agriculture

Self reliance skills involves the ability to set - up an enterprise, it is different from being employed (I kwuanusi,2011). According to Nwokolo (2004) this ability should be acquired and should differ in some respect from the ability acquired to enable a person obtain paid employment .Etuibon and Udofia(2009) referred to self reliance skills as optimal utilization of local resource with well coordination of sustainable development. A self reliant person is interchangeably called the manager, innovator decision maker, organizer, co-odinator.The integration of self reliance skills in food an nutrition curriculum expose the students to resource available in their immediate environment for instruction and at the same time bring students to real world activities. Usually, the students interest is captured and sustained through this exposure, student gain scientific skills which they will use in their future life for self reliance

\section{Careers in Food and Nutrition and Needed for Self -Reliance}

Food science,food science and technology ,Catering and hotel management, pharmacy and chemical technology deals with chemistry,engineering, microbiology pschology related aspects of foods. Application of food or chemical processes in practical and mechanical service to industry.Its targets at training the learners ability to maintain and service a wide range of technical equipments analye,formulate new products and monitor environment. Training in food and nutrition career which is practical in nature could be easily adopted as well as small -scale unite for self employment instrumentation and maintenance (Osibanjo, 2004). Thus the role of teacher in teaching food and nutrition is to create varied opportunity for students to engage in activities that will enable them make sense of the world around them, make new discoveries, solve interesting issues and develop skills that are sustainable driven.Adipere(2010)

\section{Food and Nutrition Curriculumn that can Promote the Acquisition of self Reliance Skills in the Students}

\begin{tabular}{|c|c|c|c|}
\hline $\begin{array}{l}\text { Food and } \\
\text { Nutrition } \\
\text { Topics }\end{array}$ & Self Reliance Skills & Materials & Application \\
\hline $\begin{array}{l}\text { 1.Special } \\
\text { diet }\end{array}$ & $\begin{array}{l}\text { Making special tailored } \\
\text { meals such as meal for } \\
\text { A).pregnant woman- } \\
\text { eg mxed fruit juicr/drink, } \\
\text { lasagna or bolagna } \\
\text { packed and seal saurces } \\
\text { B.) Obesed - eg } \\
\text { defluccating drnks from } \\
\text { zobo, ginger c).under } \\
\text { weght-bread and butter } \\
\text { smear } \\
\text { D.) lactatng mothers- }\end{array}$ & $\begin{array}{l}\text { Zobo flower,Ginger } \\
\text { powdwe, bread } \\
\text { butter,fresh fish.beef or } \\
\text { mutton, pepper,flour } \\
\text {,carbonated water } \\
\text {,phosphoric acid,pot clay } \\
\text { heat sources eg fire wood }\end{array}$ & $\begin{array}{l}\text { 1.Zobo , ginger or fruits extract } \\
\text { can be mixed with carbonated } \\
\text { water, add sugar and drops of } \\
\text { flavor .it could be cold and sold } \\
\text { Fresh } \\
1 . \text { Zobo , ginger or fruits extract } \\
\text { can be mixed with carbonated } \\
\text { water, add suger and drops of } \\
\text { flavour .it could be cold and } \\
\text { sold } \\
\text { 3.Cuts of meats, fish could be } \\
\text { scaled, washed and cooked with }\end{array}$ \\
\hline
\end{tabular}




\begin{tabular}{|c|c|c|c|}
\hline & $\begin{array}{l}\text { eg pepper soup of } \\
\text { different meat sources. }\end{array}$ & & $\begin{array}{l}\text { codiments and or sasoning ,this } \\
\text { can be sold hot for lactating } \\
\text { mother in the hospitals and } \\
\text { delivering environment. }\end{array}$ \\
\hline $\begin{array}{l}\text { 2.Kitchen } \\
\text { manageme } \\
\text { nt }\end{array}$ & $\begin{array}{l}\text { A) Designing kitchen } \\
\text { using the L, U, OR } \\
\text { CORRIDOR standard for } \\
\text { kinds of kitchen. } \\
\text { Detached or attached } \\
\text { building could be given } \\
\text { any of the design } \\
\text { Kitchen remodelling }\end{array}$ & $\begin{array}{l}\text { PENCI L, CARD BOARD } \\
\text { SHEET, RULES,DRAWING } \\
\text { BAORD, T- } \\
\text { square, rules, eraser, laminat } \\
\text { ing polyethene laminating } \\
\text { machine }\end{array}$ & $\begin{array}{l}\text { On a work surface of } \\
\text { board,drawing of U,L,and or } \\
\text { corridor . shape kitchen ,laminate } \\
\text { drawing and sold to builders and } \\
\text { local buiding contractors }\end{array}$ \\
\hline $\begin{array}{l}\text { 3.Codiment } \\
\text { and } \\
\text { seasoning }\end{array}$ & $\begin{array}{l}\text { Dried tomatoes, onions } \\
\text {,pepper curry leaves }\end{array}$ & $\begin{array}{l}\text { Wooden cabinet solar } \\
\text { drier,freshpepper, } \\
\text { tomatoes, and curry leaves }\end{array}$ & $\begin{array}{l}\text { 2.Simple sundring,grind in an } \\
\text { enclosed space,packed and sold }\end{array}$ \\
\hline 4.Sea foods & $\begin{array}{l}\text { 1. Making brined or } \\
\text { smoked, roasted, grilled } \\
\text { fishes along public } \\
\text { places or packs. } \\
\text { 2.Fish sauce packed } \\
\text {,grilled and sold. }\end{array}$ & $\begin{array}{l}\text { Fresh fish of all sorts, salt } \\
\text { oil,dried pepper,flour griller } \\
\text { packaging bages or } \\
\text { polyethene sealable bages. }\end{array}$ & $\begin{array}{l}\text { 1.Viscerated fish and then cut } \\
\text { into sizes,smear mixed with oil } \\
\text {,pepper and finally flour and grill } \\
\text { 2. Make a smaller slice ,simmer } \\
\text { the fish in oil and add } \\
\text { separately. } \\
\text { 3.Prepared sauce and heat for } \\
\text { 10-15 minute then pack in foil } \\
\text { labell and sold. }\end{array}$ \\
\hline $\begin{array}{l}\text { 5.Legumes } \\
\text { vegetables } \\
\text { cereals }\end{array}$ & $\begin{array}{l}\text { 1.Making of dried } \\
\text { vegetable,ugwu,alefo, un } \\
\text { der the sun or use solar } \\
\text { drier } \\
\text { 2.Making of steam ball } \\
\text { from cereal eg okpa,moi- } \\
\text { moi etc } \\
\text { Making local beverages } \\
\text { from millet eg kunu zaki } \\
\text {,kunu aya }\end{array}$ & $\begin{array}{l}\text { ANY edible leaf, polyethene } \\
\text { bages,flour from legumes } \\
\text {,cereal }\end{array}$ & $\begin{array}{l}\text { 1.Blanched leafe in hot water for } \\
\text { 2-4 minute and dry for days } \\
\text { packed and sold. used when } \\
\text { reconstituted } \\
\text { 2.Paste made by adding water } \\
\text { and ingriedient for flavor and } \\
\text { colourant cand be steamed } \\
\text { cooled and sold }\end{array}$ \\
\hline $\begin{array}{l}\text { 6.Mlk and } \\
\text { milk } \\
\text { products }\end{array}$ & Ice cream & $\begin{array}{l}\text { Dried Milk, egg, sugar } \\
\text {,vanilla flavour,colour }\end{array}$ & $\begin{array}{l}\text { 1. Beat the eg white, add diluted } \\
\text { milk to the beatened egg, add } \\
\text { sugar and little quantity of } \\
\text { vanilla flavour.the mixture is } \\
\text { allowed to freeze and sold as ice } \\
\text { cream. }\end{array}$ \\
\hline $\begin{array}{l}\text { 7.Poultry } \\
\text { cooking }\end{array}$ & $\begin{array}{l}\text { Fried chicken and minced } \\
\text { meat }\end{array}$ & $\begin{array}{l}\text { Chicken ,meat chopping } \\
\text { machine,churners, bowel,pr } \\
\text { eservatives, pepper, salt, sea } \\
\text { soning }\end{array}$ & $\begin{array}{l}\text { 1.Defeathered chicken , remove } \\
\text { visceral, wash, clean and smear } \\
\text { oil containing ingredient and } \\
\text { place in a churnner or } \\
\text { griller, motor griller and sold } \\
\text { 2.Chop meat, washe ,add } \\
\text { preservative and sold }\end{array}$ \\
\hline 8.fruits & $\begin{array}{l}\text { 1.Making of juice, drink } \\
\text { from whole or mixed } \\
\text { fruit }\end{array}$ & $\begin{array}{l}\text { 1.Assorted fruits ,blender, } \\
\text { packaging and sealing } \\
\text { machines, refrigerator }\end{array}$ & $\begin{array}{l}\text { 3.CRUD E OIL by local } \\
\text { extraction; fresh seed, weighed } \\
\text { and crushed using grater or }\end{array}$ \\
\hline
\end{tabular}




\begin{tabular}{|c|c|c|c|}
\hline & $\begin{array}{l}\text { 2. Making of crude oil } \\
\text { from fruits seed .eg } \\
\text { water melon ,cashew }\end{array}$ & $\begin{array}{l}\text { 2. Seed flakers or heaters, } \\
\text { crushed or water } \\
\text { extraction }\end{array}$ & $\begin{array}{l}\text { grinding machine then soak in } \\
\text { enough water and allowed for } \\
\text { 4hours. seperation would take } \\
\text { place . water would solubilize } \\
\text {,the polar side of the oil will } \\
\text { float and oil will be collected by } \\
\text { decantationand sieve separately } \\
\text { to include the oil.the fibrous } \\
\text { material in the cloth presed to } \\
\text { milk colour solution and the } \\
\text { resultant boiled for } 4-6 \text { hrs to } \\
\text { evaporate the water leaving the } \\
\text { oil.anothe way is to dry the seed } \\
\text { before soaking in water }\end{array}$ \\
\hline $\begin{array}{l}\text { 9.The art } \\
\text { of } \\
\text { entertainm } \\
\text { ent }\end{array}$ & $\begin{array}{l}\text { 2.I nterior } \\
\text { decoration, creation of } \\
\text { art commodity } \\
\text { Air liners, event manager }\end{array}$ & Ribons ,scissors ,curtains & $\begin{array}{l}\text { The knowledge of statistics and } \\
\text { matrixe at NCE, B.Sc levels } \\
\text { when applied could bring out the } \\
\text { beauty of the environment. }\end{array}$ \\
\hline $\begin{array}{l}\text { 10. Rechauf } \\
\text { fee food }\end{array}$ & $\begin{array}{l}\text { Using left over food, } \\
\text { drops or particles of from } \\
\text { food vendors, cateeners } \\
\text { and reuse them into fish, } \\
\text { dog, feeds or food. }\end{array}$ & $\begin{array}{l}\text { Leftover food, basin. heat } \\
\text { source, edible } \\
\text { gumes.package } \\
\text { material,flavourant, sealing } \\
\text { machine desecrators. }\end{array}$ & $\begin{array}{l}\text { Collect and sort .heat and add } \\
\text { edible gum,presrvatives, colour } \\
\text { and deodorants packed and } \\
\text { sold }\end{array}$ \\
\hline $\begin{array}{l}\text { 11.Beverag } \\
\text { es }\end{array}$ & $\begin{array}{l}\text { Making of beverage } \\
\text { drinks from food } \\
\text { suppliment,tea for } \\
\text { example green } \\
\text { word,TIANSHI OR GNLD } \\
\text { TEAS }\end{array}$ & $\begin{array}{l}\text { GNLD, GREEN WORD, } \\
\text { TIANSHI TEAS products } \\
\text { Sugar,kettle,stand,or } \\
\text { mobile stand, milk, cups }\end{array}$ & $\begin{array}{l}\text { Applying the soaking diluting } \\
\text {,sieving methods of making tea } \\
\text {,using hot water and sold }\end{array}$ \\
\hline
\end{tabular}

\section{The Challenge of Integration}

The learning environment and learning materials aims at equipping learning for self actualzation,so a child that is enrolled in school, one cannot claim that he or she has given the child access to formal education, if the child is denied quality education learning materials, condusive environment, qualified and motivated teachers.

Access to education implies enrolment and quality participation. Given the prevailing circumstances, one of the major challenge facing the school leaver is unemployment.To this end ,integrating the acquisition of self -reliance skill into food and nutrition curriculum will be beneficial to students in so many way .It will help the student to understand the concept ,principle and skills in science processes. This will motivate and sustain the interest of students and their desire in productive and useful activities. This supports NRC (,1996) which said that learning science is something the students do ,not something and not something that is done to them. It will make learning relevance to the student's life and help them in the economic application of food and nutrition in real life. It provide an authentic situation for learning which is the best tool for teaching science .It will help to improve the initial misconception of students about food and nutrition as an isolated slogan of facts. The students will view food and nutrition as a necessary ingredient for earning a living, thereby helping the recipients to become self reliant and contribute towards building sustainable national development. 


\section{Recommendation}

Curriculum planners should therefore be encourage to help to integrate self- reliance skills into food and nutrition curriculum for variety of opportunity in the labour market. The high level of unemployment graduates suggests that work needed to be done In preparing students, teachers education programme for training of science and home economics students. Their curriculum needs to be revisited by introducing the self reliance acquisition skills. There is also need for the creation of avenues for the training of in-service teachers on how to implement the scheme into the class room. This need for effective actualization and implementation call for the co-operation of all involved and not only by the Government for the workability of these ideas.

\section{Conclusion}

The researcher have examined the need to integrate the acquisition of self -reliance skills into food and nutrition curriculum in Nigeria. Hence, thousands of young graduates are being pumped in the labour market that cannot absorb them every year. There is, as a matter of urgency, the need for self -employment as this enhances the achievement of entrepreneurship development for sustainable national development.

\section{References}

Adipere,E.(2010) Sustainable Agriculture, a salvage to Economc crisis: The role of biology teachers. STAN 5I stannual conference proceedings publshers

Fayomi ,S.B (2007) Entrepreneurship education for employment opportunity awareness creation among undergraduate of Obafemi Awolowo University. Ife journal of educational studies. 13 (1) 57-65

I kwuanusi E.N (2007) .Implementation basic science education into Imo state and National development.Alvan journal of science, 3.(2)113

National research center NRC1996 National Education Standard Washington D.C National Academic Press

Nwokolo P.C (2004) Entrepreneurial initiatives in colleges of education programme .paper present Educational tax fund (ETF) Workshop on capacity building at FCE(T) Umunze

Osibanjo O. (2004) Mainstream the chemistry profession in Nigeria. An address presented at the luncheon of Anambra state chapter of ICCAN ,Awka

Udofia T.M (2009) Promoting and sustaining educational research for self -reliance international journal of educational research and adminitration, 6 (1) 
